\title{
A Study of the Effect of Entrance Examination of the Universities (EEOU) on the EFL Teaching Methodology in Iran
}

\author{
Hadi Salehi, Ramlee Mustapha, and Melor Binti Md Yunus \\ (Universiti Kebangsaan Malaysia, Malaysia) \\ doi:10.7575/aiac.alls.v.3n.1p.59
}

\begin{abstract}
Researchers and educators' recognition of positive and negative effects of tests on teaching and learning activities goes back at least four decades. Although educators frequently claim that they do not want to teach to a test, the reality is that every educator wants his/her students to be successful. Decision makers, teachers, and students equate this success in large part with high test scores, resulting in classroom instruction that is reflective of test practices and/or expectations. The effect that testing has on teaching and instruction is a phenomenon referred to as washback. However, this phenomenon has been examined empirically by only a few studies in the field of language testing. This qualitative study aimed to (i) investigate the existence and nature of the washback effect, and (ii) examine the role of EEOU context in promoting beneficial washback. The findings confirmed the existence of washback phenomenon in general and negative washback effects of EEOU context on language teaching and learning in particular.
\end{abstract}

\section{Introduction}

Washback or backwash refers to the influence of testing on teaching and learning (Alderson $\&$ Wall, 1993). The concept is rooted in the notion that tests or examinations can and should drive teaching, and hence learning, and is also referred to as measurement-driven instruction (Popham, 1987). In order to achieve this goal, a "match" or an overlap between the content and format of the test or the examination and the content and format of the curriculum is encouraged. This is referred to as curriculum alignment by Shepard (1991 and 1993). Although the idea of alignment - matching the test and the curriculum - has been descried by some as "unethical", and threatening the validity of test (Haladyna, Nolen, \& Haas, 1991, p. 4; Widen, O'Shea, \& Pye, 1997), such alignment is evident in a number of countries, for example, Iran. This alignment, in which a new or revised examination is introduced into the education system with the aim of improving teaching and learning, is referred to as systemic 
validity by Frederiksen and Collins (1989), consequential validity by Messick (1996), as well as test impact by Bachman and Palmer (1996) and Baker (1991).

Bachman and Palmer (1996, pp. 29-35) regard washback as a feature of a wider phenomena known as test impact. They suggest test impact should be viewed in terms of both its micro effects in a classroom as well as its macro effects on educational systems and societies. They stated that just as micro and macro economics have synergistic patterns, a synergism often exists between micro and macro test impact. In many cases, tests both influence and are influenced by the social climates in which they are used.

The focus of this study is on the washback associated with a 'high-stakes' test. High stakes tests are tests whose results '. . . are seen -rightly or wrongly- by students, teachers, administrators, parents, or the general public, as being used to make important decisions that immediately and directly affect them' (Madaus, 1988, p. 87). Their primary use is '. . . to ration future opportunity as the basis for determining admission to the next layer of education or to employment opportunities' (Chapman \& Snyder, 2000, p. 458). In this case, the highstakes test is the Entrance Examination of Universities (EEOU), taken by approximately 1.5 million Iranian candidates each year in the final year of their secondary schooling. Success in the EEOU is a prerequisite for entry to tertiary education. The results can therefore play a crucial role in decisions on university admission.

\section{Background}

Since1960s, the Entrance Examination of the Universities (EEOU) in Iran has been the sole criterion for the admission into higher education. This national test is a combination of some multiple-choice items and cloze tests regarding most of the courses that the students have been taught during a period of four years study in high school and pre-university level. It is administered in five main groups of students depending on their fields of study in high school. Some of the topics including English, Persian Literature, Arabic, and Theology will be tested for the students in all the majors. The English section of the test includes 25 multiple-choice items and a cloze test. The students are given 20 minutes, as required by this section of the test, to react to the questions. The first six or seven items are regarding grammatical points and the remaining items include vocabulary items, a short cloze passage and two short reading passages followed by some multiple-choice comprehension questions. 
Table 1: Types of items in recent English subset of EEOU

\begin{tabular}{lll}
\hline \multicolumn{1}{c}{ Type of Evaluation } & $\begin{array}{l}\text { Number } \\
\text { of Items }\end{array}$ & \multicolumn{1}{c}{ Competence (Skill) } \\
\hline $\begin{array}{l}\text { Identification of grammatically correct construction in } \\
\text { a given context }\end{array}$ & 6 & Grammar \\
$\begin{array}{l}\text { Diagnosing the correct and exact vocabulary } \\
\text { Cloze test }\end{array}$ & 5 & $\begin{array}{l}\text { Vocabulary } \\
\text { Integrative (reading, writing, and } \\
\text { grammar) }\end{array}$ \\
$\begin{array}{l}\text { Situation comprehension } \\
\text { Text comprehension }\end{array}$ & 5 & $\begin{array}{l}\text { Reading comprehension } \\
\text { Reading comprehension }\end{array}$ \\
\hline
\end{tabular}

Out of the 25 items of the test, eleven items assess exclusively grammatical competence and knowledge of discrete vocabulary items. The other fourteen items test integrative skills or reading skill. The cloze test requires students to know the correct verb form or the right preposition in a certain sentence. In some cases, it also requires understanding of relationships between adjacent sentences or clauses, asking students to choose the correct conjunction, connector or to interpret a reference. The 'situation comprehension' and 'text comprehension' items include questions that aim at testing global understanding (the general idea of the text, the intention of the text, and inferences that can be drawn from the text). In general, the questions in the examination range from those that test basic knowledge of grammar and vocabulary to those that ask for general understanding of short texts, as well as inference making of specific passages.

\section{Research context}

This section will provide important background information on the Iran educational context and will address the main features of the Iran educational system, the language education system, and English language learning and teaching context.

\section{Educational system in Iran}

The structure of the education system in Iran is basically divided into five cycles namely, preschool, primary, middle (or guidance), secondary and post-secondary (tertiary). Three outstanding characteristics of the Iranian education system must be mentioned at this point. Firstly, elementary education is mandatory under the Iranian Constitution. Secondary, due to increasing number of applicants, admission to post-secondary institutions is through a nationwide entrance examination and thus only the most talented students can enter universities. Finally, in general, education (in primary, secondary, and post-secondary levels) is free of charge though private schools and universities authorized by law are allowed to charge tuition fees. 


\section{School Education in Iran}

School education in Iran is divided into the following cycles. There are qualifying examinations to pass from one educational cycle to the next and national exams are conducted at the end of each grade of the secondary cycle. Special provision is made within the educational system for gifted and special needs children, as well as for minority groups, refugees and for non-formal education.

1) Pre-school (1-year cycle, children aged 5)

2) Primary (5-year cycle, children aged 6-10)

3) Middle or Guidance (3-year cycle, children aged 11-13)

4) Secondary (3-year cycle, students aged 14-17)

5) Pre-university (1-year cycle, students aged 18)

\section{Pre-school education cycle}

A one-year program for children five years old in which they receive the basic notions needed to enter primary schools. There is no exam at the end of this cycle and children proceed automatically to the following cycle.

\section{Primary education cycle}

The five-year primary cycle covers grades 1-5 for children 6 to 11 years old. This phase is both free and compulsory. Students take exams at the end of each year on which their promotion to the following grade is based. At the end of the grade 5, students take a nationwide examination. Those who pass the exam are qualified to proceed to the next cycle.

\section{Middle (Guidance) cycle}

This cycle covers grades 6 to 8 for children 11 to 13 years old. Like the preceding cycle, this cycle also provides students with general education. In this phase, the abilities as well as the interests of students are recognized, so they become prepared to decide which branch (academic or technical/vocational) they intend to choose in the next cycle. At the end of the guidance cycle, students take a regional examination under the supervision of provincial boards of education. Those who pass the examination are eligible to proceed to the next cycle i.e., secondary cycle. 


\section{Secondary education cycle}

This is a three-year stage which covers grade 9 to grade 11, from age 14 to 17 . Secondary education is divided into two main branches namely, academic/general and technical/vocational. The choice of either branch is up to pupils themselves. The academic branch, also known as the "theoretical branch" is divided into four mainstreams namely, literature and culture, socio-economic, physics-mathematics, and finally experimental sciences. The technical/vocational branch is particularly designed to train technicians for the labor market. This branch covers three mainstreams namely, technical, business/vocational, and agriculture. There are specific subject and performance requirements for admission to some secondary programs. National examinations are conducted at the end of each grade during the secondary cycle

\section{Pre-university cycle}

Students who complete the general/academic track in upper secondary school and pass a national examination are eligible to enter the pre-university cycle. This phase of education lasts for one year (completion of 24 semester credits) leading to the Certificate of Completion/Diploma. Students who complete the pre-university cycle are eligible to take the EEOU (Entrance Examination of Universities) for admission to the first year of undergraduate study.

\section{University entrance examination}

There is a fierce competition among high-school graduates in Iran to pass the centralized nationwide university entrance examination. Ministry of Science, Research, and Technology has set up the Education Evaluation Organization (EEO) to take care of all aspects of this big exam. Every year the EEO manages to select almost 150,000 students to enter universities out of 1.5 million high school graduates participating in a tough 4.5 - hour multiple-choice exam. A few weeks after the big exam day, each participant receives a score sheet, and a list of Field-Department-University (FDU), displaying each field of study in the universities, departments along with their capacity for that year (e.g., the Software Engineering field of Computer Engineering department at Tehran University). The eligible participants (those who have scored enough to be allowed to declare their FDU priorities) fill out a priority indication form, and declare the FDUs they like to enter, in the order of their preference. The EEO processes the forms, and considering the total score, the participant's FDU priority list, and some other selection rules, enters the accepted participants' names in the list of each FDU, 
until all capacities are exhausted. Those who are not entered in a list are considered failed and may try again next year. Each accepted participant's name might be entered in only one list.

\section{The university entrance exam crisis in Iran}

In Iran, as in many other countries where a university entrance exam is the sole criterion for student selection, limited space and resources have restricted many talented and enthusiastic applicants seeking access to higher education. Consequently, the phenomenon of the university entrance exam has caused discontent and conflict.

In June each year, high school graduates in Iran take the stringent, centralized nationwide university entrance exam (EEOU) seeking a place in one of the public universities. The competition is fierce, the exam content rigorous, and the seats at universities limited. In recent years, although the government has responded to the demands for improved access and to a rapid increase in the rising number of applicants by enlarging the capacity of universities and creating Azad University, public universities are still only able to accept 10 percent of all the applicants.

EEOU is a comprehensive, 4.5-hour multiple-choice exam that covers all subjects taught in Iranian high schools - from math and science to Islamic studies and foreign language. The exam is so stringent that normally students spend a year preparing for it; those who fail are allowed to repeat the test in the following years until they pass it. The Ministry of Science, Research, and Technology has established the Education Evaluation Organization to oversee all aspects of the test.

EEOU, especially in recent years, has further contributed to the massive brain drain from Iran and has created psychological and social problems such as anxiety, boredom, and hopelessness among the youth who fail the test. One of the most important drawbacks is the nature of the test itself. As in many other countries where only a long multiple-choice, mostly memory-based exam is used to select qualified applicants to enter universities, Iranian schools have been turned into factories for exam cramming.

As the EEOU crisis persists, authorities are contemplating a replacement mechanism for student selection. One of the options being considered is to use the cumulative grade-point average (GPA) of the final three years of high school to admit students. While this policy seems more humanistic and fair than using a single exam to measure students' preparedness, it 
still cannot ensure fairness or reveal students' aptitude for further learning. Perhaps incorporating interviews, essay writing, and aptitude tests, in addition to GPA would be a more effective way of measuring students' qualifications to enter universities.

\section{Statement of the problem and significance of the study}

Cheng (2005) states that it is worthwhile investigating first the nature of examination and/ or assessment in teaching and learning, then the nature of washback effect and the conditions under which it operates. She (ibid) also points out that, "if a test is supposed to be good, it would most likely drive teaching and learning, especially when the test is primarily used for selection purposes" (p. 40). Following such a routine of thought, therefore, it is worth identifying whether EEOU, as a public and large-scale examination which serves selection purposes (Farhady, Birjandi, \& Jafarpoor, 1993), influences teaching and learning activities performed in Iranian high school EFL classes, and whether such an impact brings about positive or negative consequences.

Since the ultimate targets of the washback effect are enhancing students learning and bettering English teachers' performance in the classrooms, this qualitative study aims to (i) investigate the existence and nature of the washback effect, and (ii) examine the role of EEOU context in promoting beneficial washback. To achieve the purpose of the study the following research questions were proposed:

1) Does washback effect exist in Entrance Examination of Universities?

2) Is EEOU context influential in promoting beneficial washback?

This issue is worth scrutiny because more than 1.5 million Iranian students take this exam annually and it is considered as the sole criterion for admission into state universities.

\section{Methodology}

\section{Participants}

Teachers

Among the factors that can mediate the washback effect is the teacher (Wall, 1996) and his/her perceptions about the examinations, its nature, purposes, relevance in the context, etc. These aspects were explored in an interview with five Iranian high school English teachers. 
They were three women and two men with more than ten years of teaching experience in the high school and had attended a number of in-service training workshops.

\section{Students}

Ten students of the aforementioned English teachers were randomly requested to take part in interviews and answer the researchers' questions. The interview done with these students dealt with their perceptions about the importance of EEOU, the effects of this exam on their English learning and required strategies for overcoming EEOU dam.

\section{Instrument}

Group Interviews

The selected teachers and students were requested to participate in the separate group interviews. According to Kreuger (1988), small groups (4-6 people) are preferable when the

participants have a great deal to share about the topic or have had intense or lengthy experiences with the topic of discussion. Therefore, one group of five teachers and two groups of students each comprising five participants were formed to facilitate the discussion process.

\section{Results and discussion}

The interview questions for teachers were designed to explore teachers' beliefs about EEOU. The interview examined whether teachers believed that their teaching had been influenced by the administration of EEOU; and whether they reported changes in their teaching practices as a result of the implementation of the EEOU techniques. All the interview questions for the teachers were based on three washback hypotheses taken from Alderson and Wall (1993): "A test will influence what teachers teach"; "A test will influence how teachers teach"; and "Tests will have washback effects for ... some teachers, but not for others" (pp. 120-121).

The students attending the interview were also requested to express their perceptions and attitudes about EEOU items and the way teachers prepare them for this national exam. The fourth grade students believed that their teachers focus more on the skills and points which are tested in EEOU. Based on their assertions, the teachers did not focus on listening and writing skills at all and little attention was paid to pronunciation exercises as well. Most of the class time was devoted to clarifying grammatical points and practicing reading comprehension texts. 
The negative effects of EEOU context was less on the methodology of teachers who were in charge of teaching English in grades one to three. These English teachers tried to base their teaching methodology according to the recommendations of the Ministry of Education (ME) in Iran regarding the suitable weight and time which should be devoted to each skill in general and each activity in particular.

One important point was that all the teachers were concerned about their students' proficiency levels. They all believed that speaking skill was sacrificed for the sake of other skills which were covered in EEOU. Hence, it can be concluded that EEOU context had negative washback effects on the English teachers' methodology and learners' strategies for English learning. After four years of studying English in high school, students were not capable to speak English and even they could not use simple conversational phrases in real-life situations.

\section{Conclusion and implications}

There is optimism that the entrance examination of universities in Iran could become obsolete in the near future, since a declining birth rate will make it possible that all students will be accepted to universities. As if predicting the current situation of Iran, Glaser asserted that it "seems clear that we are over the threshold in the transition from education as a highly selective enterprise to one that is focused on developing an entire population of educated people. A selective system is no longer the prevalent educational demand" (Glaser, 1981, as cited in Johnston, 1989, p. 509). However, since the divisions between universities of different rank are regarded as being very important by people in Iran, and there is a widespread belief that entering renowned universities guarantees a better carrier after graduation, it is not very likely that the examinations will readily be discarded. What is needed in such a situation is rational argument based on empirical evidence indicating the actual power of the examinations, whether negative or positive.

The results of this study might be of use to three groups of people: a) at the micro level, to teachers and students, as the two elements of teaching and learning process, b) at the macro level, to the EEOU developers and administrators, curriculum designers as well as policy makers who are, according to Bachman and Palmer (1996, p. 34), "all concerned about the impact of testing on the educational system and society", and c) to the researchers in the field, 
especially those who are more concerned with providing empirical support for washback phenomenon.

\section{References}

Alderson, J. C., \& Wall, D. (1993). Does washback exist? Applied Linguistics, 14,115-129.

Bachman, 1. F., \& Palmer, A. S. (1996). Language testing in practice: Designing and developing useful language tests. Oxford: OUP.

Baker, E. L. (1991). Issues in policy, assessment, and equity. Paper presented at the national research symposium on limited English proficient students' issues: Focus on evaluation and measurement, Washington, DC.

Chapman, D. W., \& Snyder, C. W. (2000). Can high stakes national testing improve instruction: Reexamining conventional wisdom. International Journal of Educational Development, 20, 457-474.

Cheng, L. (2005). Changing language teaching through language testing: A washback study. Cambridge: Cambridge University Press.

Farhady, H., Birjandi, P., \& Japarpoor, A. (1993). Testing language skills: From theory to practice. Tehran: The Center for Studying and Compiling University Books in Humanities, SAMT.

Frederiksen, J. R. and Collins, A. (1989). A Systematic approach to educational testing, Educational Researcher, 18, 27-32.

Glaser, R. (1981). The future of testing: A research agenda for cognitive psychology and psychometrics. American Psychologist, 36, 923-036.

Haladyna, T. M., Noleb, S. B., \& Haas, N. S. (1991). Raising standardized achievement test scores and the origins of test score pollution. Educational Research, 20 (5), 2-7.

Kreuger, R. A. (1988). Focus groups: A practical guide for applied research. London: Sage.

Madaus, G.F., (1988). The influence of testing on the curriculum. In: Tanner, L.N. (Ed.), Critical issues in curriculum: Eighty-seventh yearbook of the national society for the study of education (Part 1) (pp. 83121). Chicago: University of Chicago Press.

Messick, S. (1996). Vlidity and washback in language testing. Language Testing, 13, 241-256.

Popham, W. J. (1987). The merits of measurement-driven instruction, Phi Delta Kappan 68, 679-682.

Shepard, L. A. (1991). Psychometrician's beliefs about learning. Educational Research, 20(6), 2-16.

Shepard, L. A. (1993). The place of testing reform in educational reform: A reply to Cizek. Educational Research, 22(4), 10-14.

Wall, D. (1996). Introducing new tests into traditional systems: Insights from general education and from education theory. Language Testing, 13, 234-354.

Widen, M. F., O'Shea, T., \& Pye, I. (1997). High-stakes testing and the teaching of science. Canadian Journal of Education, 22, 428-444. 